\title{
Unexpected extremity injury in orthopaedic emergency service
}

\author{
Mehmet Arican, ${ }^{1}$ Yalçın Turhan ${ }^{2}$
}

${ }^{1}$ Department of Orthopedic and Traumatology, Duzce University School of Medicine, Duzce, Turkey

${ }^{2}$ Department of Orthopaedics and Traumatology, Duzce Universitesi, Duzce, Turkey

\section{Correspondence to}

Dr Mehmet Arican,

ari_can_mehmet@hotmail.com

Accepted 10 January 2019

\section{DESCRIPTION}

Agricultural machines and equipment have been used widely in our country like all over the world by farmers, and some of them play important roles in some accidents causing severe morbidities even mortality. ${ }^{1-3}$ One of them is called as 'pat pat' which is a grubber or single-axle two-wheel tractor used for vineyard, garden and field works (figure 1). Pat-pat causes severe morbidities and mortalities frequently due to its characteristics like lacking of a safety brake and balancing systems. ${ }^{1}$

A previously healthy 27-year-old man was admitted to our emergency room with a severely crushed left lower extremity after a pat-pat accident 1 hour after the trauma. He was an agricultural labourer at the field, and his left lower extremity was stuck in the pat-pat. On history, during garden fields preparation process and planting with pat-pat, a large stone stood in front of it. So, the patient left the pat-pat on its braking system to remove the stone, but the braking system became inactive, and it ran over his left leg. His clothes were also caught by the grubber.

At the time of admission, the patient had dirty and torn clothes on the left lower extremity, and the left leg had an obvious deformity with very limited range of motion. Also the blades of the grubber were stuck on the bone but there was no major soft tissue defect on the affected leg. On physical examination, there were swelling, ecchymosis on proximal leg and also multiple abrasions. There was no active bleeding at the injury site or any major injury in other parts of the body. The Glasgow Coma Scale of the patient was 15 without any respiratory distress or haemodynamic abnormalities with normal pulse rate, free airway and a $98 \%$ oxygen saturation without oxygen supplement, but his left lower extremity was cool, paralysed and numb, and the distal pulses were non-palpable (figure 2). The Mangled Extremity Severity Score of the patient was 7 (very high energy skeletal injury: 4 points, limb ischaemia: 3 points, shock and age: 0 points).

Check for updates

(C) BMJ Publishing Group Limited 2019. No commercial re-use. See rights and permissions. Published by BMJ.

\begin{tabular}{l}
\hline To cite: Arican M, \\
Turhan Y. BMJ Case \\
Rep 2019;12:e228566. \\
doi:10.1136/bcr-2018- \\
228566
\end{tabular}

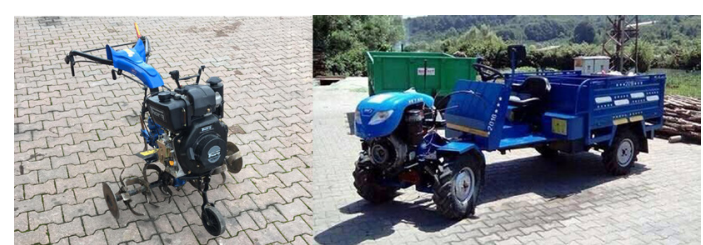

Figure 1 Agricultural machines with grubber or singleaxle two-wheel tractor is called pat-pat.

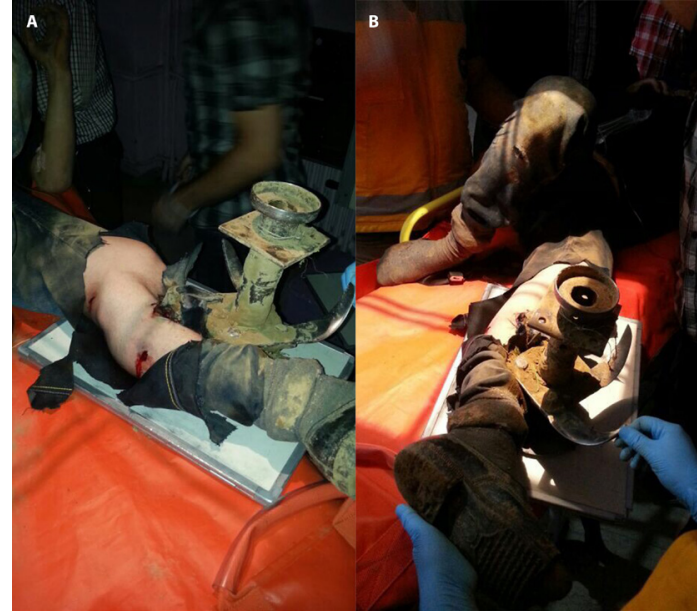

Figure 2 The patient's left lower extremity was stuck in the pat-pat with grubber and deformity.

Conventional radiographic examination of his left lower extremity revealed a displaced tibial plateau fracture (figure 3). There was no outflow in the dorsalis pedis, tibialis posterior and popliteal arteries on Doppler ultrasonographic examination. A diagnosis of comminuted tibial plateau fracture with a popliteal artery and vein injury was made.

The patient's left lower extremity was removed from the grubber under general anaesthesia in emergency operating room. The metal grubber removed

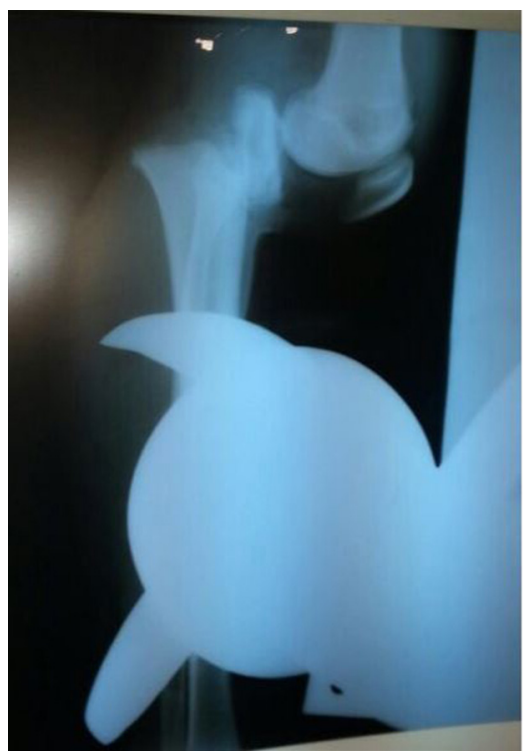

Figure 3 Lateral tibia of his left lower extremity revealed a displaced tibial plateau fracture. 


\section{Learning points}

In our country as in all over the world, agriculture machinesrelated accidents are an important reasons for morbidity and mortality.

- Early management of crush injuries is important to achieve satisfactory results.

- Possible vascular damage should be kept in mind in all types of major extremity traumas.

from the leg was about $15 \mathrm{~kg}$ in weight and $45 \mathrm{~cm}$ in width with four-row blades. The open tibial plateau fracture was debrided and fixed with a unilateral external fixator after reduction under fluoroscopy. The injured popliteal artery and vein were repaired with saphenous vein grafting by cardiovascular surgery department. The patient was able to walk with full weight bearing at 6 months after operation.
Contributors MA: the idea of research and hypothesis generation, design, manuscript preparation; responsibility for conducting experiments, management of patient, organising and reporting data, literature search, writing manuscript, performed surgery, reworking the final, before submission version of the manuscript YT: organising and reporting data, literature search, reworking the final, before submission version of the manuscript, data collection and analysis.

Funding The authors have not declared a specific grant for this research from any funding agency in the public, commercial or not-for-profit sectors.

Competing interests None declared.

Patient consent for publication Obtained.

Provenance and peer review Not commissioned; externally peer reviewed.

\section{REFERENCES}

1 Küçüker H. Analysis of deaths caused by pat-pat accidents in Turkey. Traffic Inj Prev 2012;13:209-11.

2 Nogalski A, Lübek T, Sompor J, et al. Agriculture and forestry work-related injuries among farmers admitted to an emergency department. Ann Agric Environ Med 2007:14:253-8.

3 Carlson KF, Gerberich SG, Church TR, et al. Tractor-related injuries: a population-based study of a five-state region in the Midwest. Am J Ind Med 2005;47:254-64.

Copyright 2019 BMJ Publishing Group. All rights reserved. For permission to reuse any of this content visit https://www.bmj.com/company/products-services/rights-and-licensing/permissions/

BMJ Case Report Fellows may re-use this article for personal use and teaching without any further permission.

Become a Fellow of BMJ Case Reports today and you can:

- Submit as many cases as you like

- Enjoy fast sympathetic peer review and rapid publication of accepted articles

- Access all the published articles

- Re-use any of the published material for personal use and teaching without further permission

For information on Institutional Fellowships contact consortiasales@bmjgroup.com

Visit casereports.bmj.com for more articles like this and to become a Fellow 